\title{
Prevailing Theoretical Approaches Predicting Sustainable Business Models: A Systematic Review
}

\author{
João J. Ferreira, Cristina I. Fernandes, Pedro M. Veiga, and Mathew Hughes \\ Accepted for publication at International Journal of Productivity and Performance \\ Management
}

Ferreira, J.J., Fernandes, C.I., Veiga, P.M., and Hughes, M. (2021), "Prevailing Theoretical Approaches Predicting Sustainable Business Models: A Systematic Review", International Journal of Productivity and Performance Management, in press. DOI: 10.1108/IJPPM-12-2020-0653

\begin{abstract}
Purpose - This study aims to map scientific publications, intellectual structure, and research trends in the sustainable business models (SBM) field. Specifically, it attempts to: i) identify the fundamental contributions of research in this area of knowledge; and ii) determine the research lines that constitute the most prominent intellectual structure. We leverage these insights to formulate and propose a future research agenda for SBM.

Design/methodology/approach - We made recourse to the bibliometric, co-citation, and cluster analysis techniques. To evaluate potential patterns among articles, we analysed how articles are jointly cited. We further applied hierarchical cluster analysis to the articles and used co-citation analysis to group the interrelated articles into distinct sets.

Findings - The results enable the identification and classification of the prevailing theoretical foci in the domain of SBM: i) SBM implementation; ii) SBM challenges; iii) Institutional SBM; iv) Circular SBM; and v) Emerging SBM.

Originality/value - This study identifies, explores, analyses, and summarises the main theoretical approaches and themes surrounding SBM research to date, contributing to deepening the literature by identifying the priority areas concerning sustainable business models and encouraging future research of an internationally excellent standard.
\end{abstract}

Keywords: sustainable business models; sustainability; circular economy; systematic literature review; bibliometrics.

\section{Introduction}

In the last ten years, sustainability issues have taken on special relevance (Goni et al., 2017; Filser et al., 2019). All issues related to resource depletion, land, air, and water pollution, low levels of human development, low economic growth, and climate change have disturbed society in general, especially policymakers, professionals and scholars (Ferreira et al., 2019). Sustainability in business is defined by Schaltegger et 
al. (2012) as a voluntary activity to contribute solutions to societal and environmental problems by creating profits.

Sustainable business models (SBM) can be treated, rather than as a strategy, as a more mature approach to sustainable business practices. SBMs are assumed to encompass changes made to implement sustainability issues at the strategic level and result from processes that reshape the business model structures (Rudnicka, 2016; Kraus et al., 2018). Considering the Triple Bottom Line, Elkington (1997) proposes a definition of sustainable business models that will incorporate a triple bottom line approach comprised of stakeholder, environmental and societal interests. Sustainable business models, then, have ay their heart some component of societal or environmental welfare, and studies find that an accumulation of such green activities and growth at the country level can result in economic benefits (Fernandes et al., 2021).

SBMs are essential in driving and implementing corporate innovation for sustainability and can help incorporate sustainability into business. As such, they serve as a key driver for competitive advantage (Bocken et al., 2014). For LuedekeFreund (2009), a company needs to allocate resources and coordinate activities in a value creation process that overcomes the public/private benefit discrepancy in sustainable business modelling. Generating value creation processes, defining good measures that will show environmental and social effects, and improving the nonmarket pillar are types of activities relevant to this endeavour. Thus, creating a competitive advantage through superior customer value and contributing to business and society's sustainable development are basic assumptions behind SBM (LuedekeFreund, 2010). Indeed, very recent studies assert the power of an environmental policy to product-market performance (Rahman et al., 2020). However, others suggest that any financial benefit relies first on how well the firm's activities render social performance (Gali et al., 2020). Concurrently, scholars and managers cannot lose sight of the fact that business models must ultimately create value propositions for customers before the firm itself can appropriate wealth (Powell \& Hughes, 2016). Consequently, it is increasingly essential that we take stock of existing knowledge on SBM to understand where our current knowledge is at its greatest and at its most efficient.

Special issues dedicated to this field of study have recently emerged. For example, Tseng et al. (2013) addressed sustainability through the management, 
design, and practice of the green supply chain in Asia by examining sustainable consumption and production opportunities. Boons \& Luedeke-Freund (2013) evaluated the diffusion of specific business models, such as product-service systems and the introduction of new management tools for business transition management. Dentchev et al. (2016) sought to capture research on different sustainable business models, and Dentchev et al. (2018) investigated the benefits of sustainable business models for society today.

In addition to these special issues, several authors have also carried out systematic reviews of this topic's literature. For example, Upward \& Jones (2016) created a model that allows the description of highly sustainable and successful business models, including functionally-necessary relationships. Lewandowski (2016) identified and classified the circular economy's characteristics according to a business model structure. Caldera et al. (2017) systematised the literature on how lean and green initiatives can lead to sustainable business practices. In contrast, Murray et al. (2017) outlined the circular economy's conceptualisations and origins, tracing its meanings and exploring its economics and ecology backgrounds in business and policy. Luedeke-Freund \& Dembek (2017) created a taxonomy that can serve as a basis for more unified analysis and comparison of SBM studies and new business model tools used in various disciplines and sectors. Evans et al. (2017) developed a unified theoretical perspective to understand the business model innovations that lead to improved economic, environmental, and social organisational performance.

As many business model innovations fail, however, Geissdoerfer et al. (2018b) studied why sustainable business models are prone to failure. In turn, Lahti et al. (2018) presented the core components of circular business models. They discussed the links to contingency theory, transaction cost theory, resource-based theory, network theory, industrial economics, and agency theory. By comparison, Nosratabadi et al. (2019) provided an insight into the state-of-the-art of sustainable business models in various application areas. These authors concluded that the popularity and success rate of sustainable business models have increased along with the increasing use of advanced technologies.

Across existing studies, however, what is missing a careful analysis and scrutiny of the theoretical approaches used to understand SBMs. Theories enable predictions about how, when, and why SBMs will emerge or render effects. Therefore, understanding this state-of-the-art is essential to understand where 
predictive capacity is effective and deficient and draw attention to essential questions for future research. In this context, our research question becomes: What are the prevailing theoretical approaches in the study of sustainable business models (SBM)?

Despite several systematic reviews of the literature on this subject, there has been a shortage to date a systematic review of the evolution and levels of SBM analysis to arrive at a knowledge synthesis of what is know and not known about SBM. Thus, we see that we are in the presence of a relatively fragmented field of research. We need a theoretical systematisation that allows us to contribute to advancing this area of knowledge. This study aims to map scientific publications, intellectual structure, and research trends in the area of SBMs. In a systematic review of 343 articles on SBM, our research synthesises existing studies in this field from a categorised bibliometric analysis. This research provides researchers with a more solid basis for explicitly positioning their contributions in the SBM literature and supporting future research in this research field through a systematic literature review and bibliometric analysis.

The article is structured as follows. The following section presents the theoretical background of the SMB literature. The third section presents the methodology used in this systematic review. It discusses the results regarding Sustainable Business Models' core areas, their intellectual and collaborative structures, and those resulting from co-citation networks. Finally, the last section highlights the findings and suggests avenues for future research.

\section{Theoretical Background}

Shane (2003) argued that entrepreneurship is the nexus between individuals and opportunities. Thus, sustainable entrepreneurship is widely defined as recognizing, assessing, and exploiting opportunities by individuals who create future products and services with economic, social, and ecological benefits (Patzelt and Shepherd, 2011; Neymeyer and Santos, 2018; Ferasso et al., 2020). For Cohene Winn (2007), this triple bottom line is the ideological foundation of many sustainable entrepreneurs, who reject the singular focus on financial profitability and instead build business ventures to address imperfections or market failures, such as climate change.

Like traditional entrepreneurship, the central component of a sustainable enterprise is its business model (Morris et al., 2005; Ferrasso et al., 2020; Raposo et 
al., 2020). As Zott et al. (2011) argue, all business models focus on how financial value is maintained for the firm regardless of the variables or components. As for the sustainability component of a business model specifically, there are various research streams. Stubbs and Cocklin (2008) proposed a set of normative principles that are ideally part of a sustainability-focused business model. First, organisational and cultural attributes of the company. These include community spirit, promoting employee trust and loyalty, and participation in sustainability assessments and reports. Second, performance measures, organisational goals, and values-oriented towards sustainability. For example, Hansen et al. (2009) proposed the sustainability innovation cube model to assess the effects of sustainability-oriented innovations. Other examples include product-market performance measures (Rahman et al., 2020) and social performance (Gali et al., 2020).

Boons and Lüdeke-Freund (2013) discussed the interrelationships between business models and innovation in sustainability and proposed four basic elements of a sustainable business model: i) the value proposition of products and services should focus on ecological, social, and economic value; ii) general business infrastructure and logistics guided by the principles of sustainable supply chain management; iii) interface with customers allowing close relationships between customers and other stakeholders to improve co-responsibility in production and consumption; and iv) equal distribution of costs and economic benefits among all actors involved. However, Bocken et al. (2014) summarised eight different archetypes of sustainable business models, which they then grouped into three types of business model innovation: technological, social, and organisational.

In sum, research studies have attempted to clarify sustainable business models' attributes and components, mainly from a corporate perspective. We found that the definitions of sustainable business models are closely aligned with the triple bottom line approach. In contrast, the increasing academic attention given to sustainable business models has led to conceptualizing different archetypes of these models.

\section{Methodology and data}

\subsection{Data}

Data were collected from citations and co-quotes from the Science Citation Index Expanded (SCI-Expanded), Social Science Citation Index (SSCI) and Arts \& 
Humanities Citation Index (A\&HCI), and Emerging Sources Citation Index (ESCI) compiled by Clarivate Analytics' Web of Science ${ }^{\mathrm{TM}}$ Core Collection and containing thousands of academic publications and bibliographic information on authors, affiliations, and citations.

The WoS was selected to ensure the academic quality standards of manuscripts included in this sample. The predominance of high-quality peer-reviewed journals dealing with regional innovation system-related topics is sizeable in the WoS (Ferreira et al., 2019; Mas-Tur et al., 2020). A search was carried out on the database using English language publications until 2019 and the following search criteria: TOPIC: ("sustain* business model*"). This process resulted in 343 documents. Table 1 shows the main features of the sample of documents included in our study.

Table 1 - Summary of the data sample

\begin{tabular}{lc}
\hline Description & Results \\
\hline Documents & 343 \\
Sources (Journals, Books, etc.) & 178 \\
Keywords Plus (ID) & 754 \\
Author's Keywords (DE) & 1101 \\
Period & $2001-2019$ \\
Average citations per documents & 26.1 \\
Authors & 948 \\
Author Appearances & 1055 \\
Authors of single-authored documents & 58 \\
Authors of multi-authored documents & 890 \\
Single-authored documents & 60 \\
Documents per Author & 0.4 \\
Co-Authors per Documents & 3.1 \\
\hline
\end{tabular}

\subsection{Method}

For statistical and analytical methods, a descriptive analysis of the 343 publications resulting from the research was carried out in the first instance to analyze the database. Graphical methods, frequency tables and descriptive measures (mean and standard deviation) illustrate the data and understand its underlying features. Subsequently, the bibliometric methodology of co-citation analysis referred to in White and McCain's study (White \& McCain, 1998), was applied to analyse the most relevant publications on SBMs. 
The number of times that two documents or authors dealing with SBMs are cited together in the resulting universe of publications is analysed to obtain relationships in citations and map the dominant approaches to researching the subject of SBMs. To map the articles visually, network analysis was used to obtain a twodimensional graph, where the links of co-citations between the articles can be observed. After the graphical mapping, a hierarchical cluster analysis is applied to group related articles into distinct sets (Ferreira et al., 2019; Kraus et al., 2020; MasTur et al., 2020).

All calculations were performed using IPM-SPSS software version 26.0 (IBM Corporation, USA), Microsoft Excel 2010 (Microsoft Corporation, Washington, USA) and NetDraw software version 2.148 (Borgatti, 2002).

\section{Results}

\subsection{Articles, Sources and Countries}

The 343 articles were published between 2001 ( 1 article) and 2019 (81 articles), corresponding to an average annual growth rate of $8.8 \%$. This set of articles are cited 8.943 times and on average 26.1 times per article.

Figure 1 shows the evolution of published articles and citations according to the year, with publications on the subject being rare until 2010, with sustained growth since 2014. The average year of publication of the articles is 2016.2, demonstrating a very recent and expanding scientific field. There has been exponential growth in citations per year in recent years, with 489 citations in 2016 and 2,305 in 2019.

As far as the articles are concerned, the five articles with the highest number of citations are:

1. Bocken, N. M. P., Short, S. W., Rana, P., \& Evans, S. (2014). A literature and practice review to develop sustainable business model archetypes. Journal of Cleaner Production, 65, 42-56. (850 citations; 121.4 citations per year)

2. Boons, F., \& Luedeke-Freund, F. (2013). Business models for sustainable innovation: state-of-the-art and steps towards a research agenda. Journal of Cleaner Production, 45, 9-19. (664 citations; 83.0 citations per year) 
3. Stubbs, W., \& Cocklin, C. (2008). Conceptualising a 'sustainability business model'. Organization \& Environment, 21(2), 103-127. (418 citations; 32.2 citations per year)

4. Boons, F., Montalvo, C., Quist, J., \& Wagner, M. (2013). Sustainable innovation, business models and economic performance: an overview. Journal of Cleaner Productio, 45, 1-8. (360 citations; 45.0 citations per year)

5. Murray, A., Skene, K., \& Haynes, K. (2017). The Circular Economy: An Interdisciplinary Exploration of the Concept and Application in a Global Context. Journal of Business Ethics, 140(3), 369-380. (342 citations; 85.5 citations per year)

Table 2 presents the ten journals with the largest number of published articles and the largest number of citations. The journals with the most SBM publications are, Journal of Cleaner Production (79 articles), Sustainability (41 articles), and Business Strategy and the Environment (9 articles). For the highest number of citations, the journals with the highest frequency are Journal of Cleaner Production (4,429 citations), Sustainability (565 citations), and Organization \& Environment (551 citations). 
Figure 1 - No. of articles and citations by year

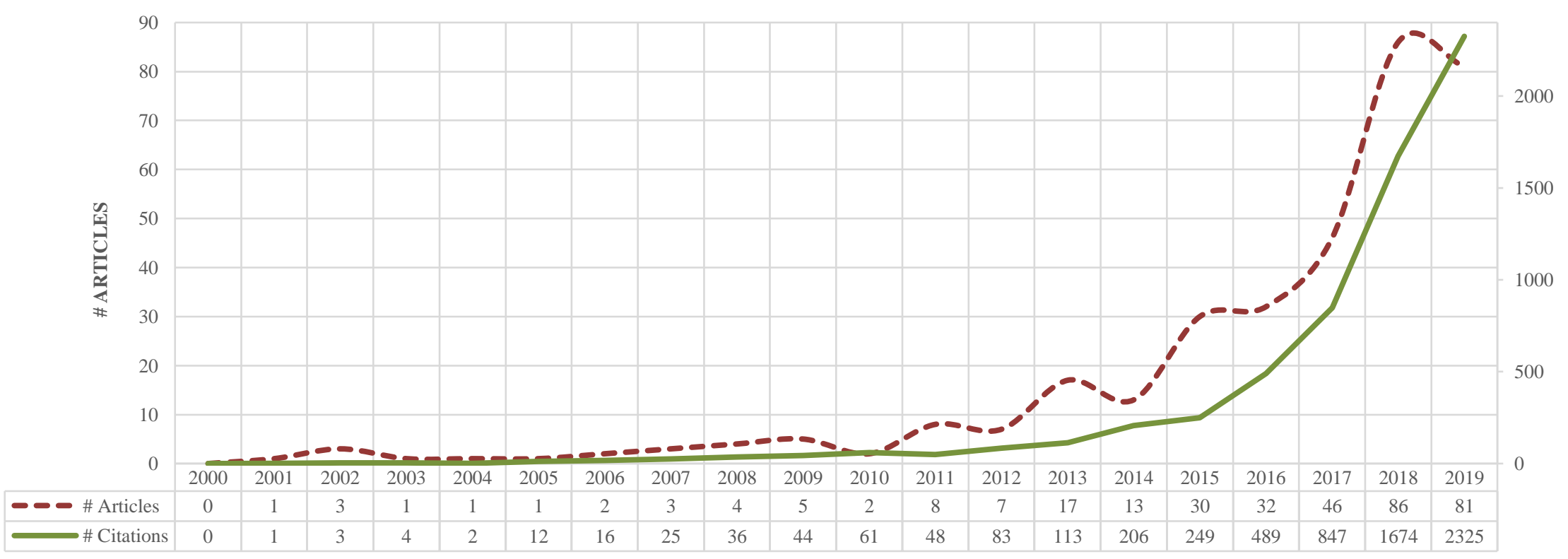


Table 2 - Distribution of articles and total citations by journal

\begin{tabular}{|c|c|c|c|}
\hline Source & $\begin{array}{c}\# \\
\text { Article } \\
\text { s } \\
\end{array}$ & Source & $\begin{array}{c}\# \\
\text { Citations }\end{array}$ \\
\hline Journal of Cleaner Production & 79 & Journal of Cleaner Production & 4429 \\
\hline Sustainability & 41 & Sustainability & 565 \\
\hline Business Strategy and the Environment & 9 & Organization \& Environment & 551 \\
\hline Health Affairs & 4 & Journal of Business Ethics & 381 \\
\hline Journal of the American Pharmacists Association & 4 & Business Strategy and the Environment & 353 \\
\hline British Food Journal & 3 & Resources Conservation and Recycling & 184 \\
\hline $\begin{array}{l}\text { Corporate Social Responsibility and Environmental } \\
\text { Management }\end{array}$ & 3 & MIT Sloan Management Review & 165 \\
\hline Journal of Business Ethics & 3 & Health Affairs & 134 \\
\hline Resources Conservation and Recycling & 3 & Journal of Industrial and Production Engineering & 111 \\
\hline Sustainable Production and Consumption & 3 & $\begin{array}{l}\text { Journal of the American Medical Informatics } \\
\text { Association }\end{array}$ & 98 \\
\hline
\end{tabular}

Figure 2 shows the evolution of the number of articles published by source. The Journal of Cleaner Production and Sustainability are the primary sources for the increasing number of articles published in recent years.

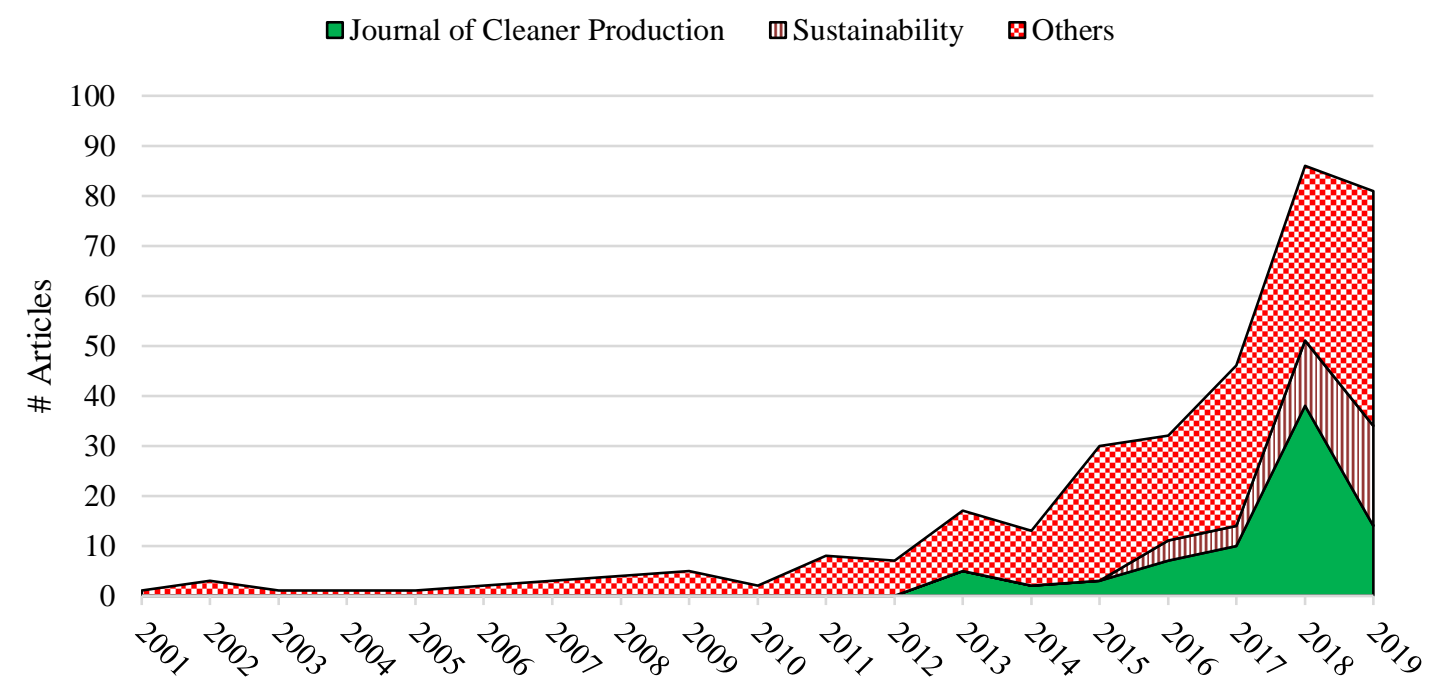

Figure 2 - Distribution of articles by journal and year

The countries with the most authors in the field are the USA (136 authors), the UK (98 authors), Germany (54 authors), and the Netherlands (52 authors). In terms of published articles, 73 articles were authored from the UK, 72 from the USA, 36 from the Netherlands, and 32 from Germany. 
Table 3 - Countries with the largest number of publications and authors

\begin{tabular}{lc|lc}
\hline Countries & \# Articles & Countries & \# Authors \\
\hline UK & 73 & USA & 136 \\
USA & 72 & UK & 98 \\
Netherlands & 36 & Germany & 54 \\
Germany & 32 & Netherlands & 52 \\
Sweden & 30 & Italy & 45 \\
Italy & 29 & Peoples Republic of China & 42 \\
Peoples Republic of China & 26 & Sweden & 35 \\
Spain & 19 & Australia & 27 \\
Australia & 18 & Canada & 27 \\
Canada & 16 & Spain & 25 \\
\hline
\end{tabular}

\subsection{Co-citation analysis}

After initially analysing the body of 343 articles, it was necessary to establish a criterion for the definition of those articles that constitute the basis to respond to this study's objectives. According to the criterion of relevance, which should delimit the set of articles for inclusion from an original (high) number of references, thus contributing to an enrichment of the analysis, articles were selected with at least 20 citations for a total of 77 articles. The distribution of these 77 articles by journal reveals that the Family Business Review has the largest number of articles (4 articles). In second place appear the Entrepreneurship Theory and Practice, Journal of Family Business Strategy, and Journal of Small Business Management, with three articles. As for citations, the journals Entrepreneurship Theory and Practice (539 citations), Family Business Review (271 citations), and Trends in Plant Science (254 citations) have the highest number of citations.

As the bibliometric methodology used is based on the analysis of co-citations to determine the most relevant SBM publications, the co-citations matrix was built based on the number of times that two documents or authors dealing with SBM are cited together in the universe of publications. This analysis aims to assess the citations' relationships to ultimately map the dominant SBM research approaches. After constructing this matrix, 17 were eliminated due to the absence of co-citations or that only had a co-citation with one article. Following this process, 60 articles remained and were entered into he subsequent co-citations analysis. By applying network theory to the nuance of co-citations, a network was created to analyse the 
relationship between the 60 articles (Figure 3). The grouping of the articles that appear in the matching network was determined by cluster analysis based on Ward's hierarchical method. The articles included in each of the determined groups are presented in Table 4.

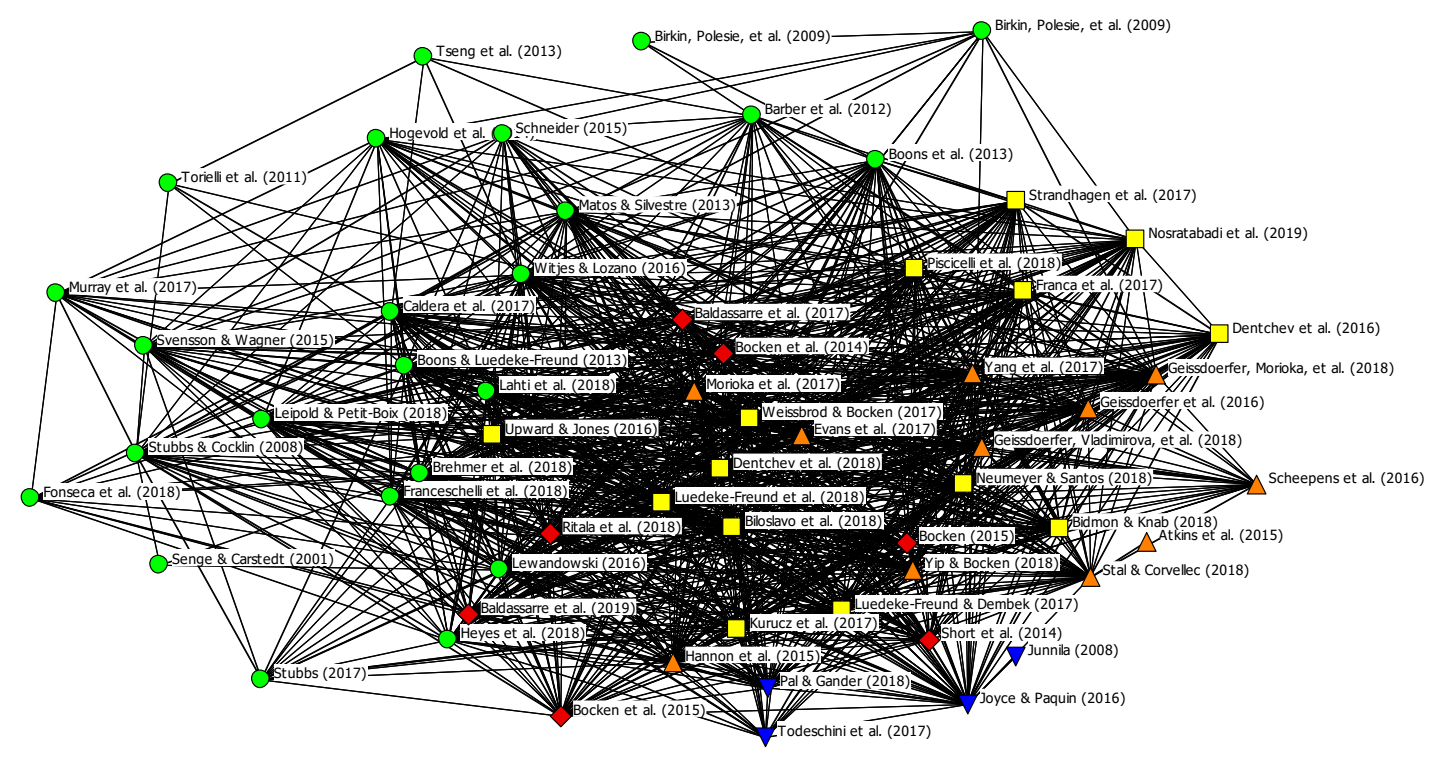

Figure 3 - Co-citations network and Cluster analysis

Table 4 - Articles used in co-citations analysis

\begin{tabular}{|c|c|c|c|c|c|}
\hline Article & Cluster & Article & Cluster & Article & Cluster \\
\hline Barber et al. (2012) & \multirow{24}{*}{ 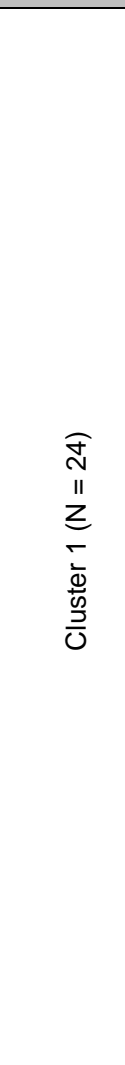 } & \multirow{14}{*}{$\begin{array}{l}\text { Bidmon \& Knab (2018) } \\
\text { Biloslavo et al. (2018) } \\
\text { Dentchev et al. (2016) } \\
\text { Dentchev et al. (2018) } \\
\text { Franca et al. (2017) } \\
\text { Kurucz et al. (2017) } \\
\text { Luedeke-F. \& Dembek } \\
\text { (2017) } \\
\text { Luedeke-F. et al. (2018) } \\
\text { Neumeyer \& Santos (2018) } \\
\text { Nosratabadi et al. (2019) } \\
\text { Piscicelli et al. (2018) } \\
\text { Strandhagen et al. (2017) } \\
\text { Upward \& Jones (2016) } \\
\text { Weissbrod \& Bocken (2017) }\end{array}$} & \multirow{14}{*}{ 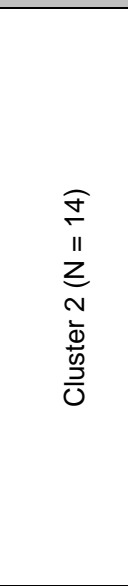 } & Baldassarre et al. (2017) & \\
\hline Birkin, C. et al. (2009) & & & & Baldassarre et al. (2019) & $\widehat{\nwarrow}$ \\
\hline Birkin, P. et al. (2009) & & & & Bocken et al. (2014) & $z^{\prime \prime}$ \\
\hline Boons et al. (2013) & & & & Bocken (2015) & $\begin{array}{ll}z \\
y\end{array}$ \\
\hline Boons \& Luedeke-F. (2013) & & & & Bocken et al. (2015) & $\Phi$ \\
\hline Brehmer et al. (2018) & & & & Ritala et al. (2018) & $\frac{\underline{n}}{\underline{D}}$ \\
\hline Caldera et al. (2017) & & & & Short et al. (2014) & \\
\hline Fonseca et al. (2018) & & & & Joyce \& Paquin (2016) & \\
\hline Franceschelli et al. (2018) & & & & Junnila (2008) & $\bar{\sigma}$ \\
\hline Heyes et al. (2018) & & & & Pal \& Gander (2018) & $\frac{n}{2} \geq$ \\
\hline Hogevold et al. (2014) & & & & Todeschini et al. (2017) & \\
\hline Lahti et al. (2018) & & & & & \\
\hline Leipold \& Petit-Boix (2018) & & & & & \\
\hline Lewandowski (2016) & & & & & \\
\hline Matos \& Silvestre (2013) & & Atkins et al. (2015) & \multirow{10}{*}{ 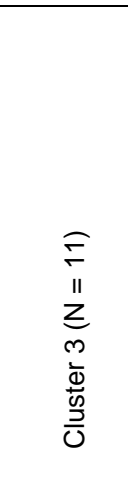 } & & \\
\hline Murray et al. (2017) & & Evans et al. (2017) & & & \\
\hline Schneider (2015) & & Geissdoerfer et al. (2016) & & & \\
\hline Senge \& Carstedt (2001) & & $\begin{array}{l}\text { Geissdoerfer, M. et al. } \\
(2018)\end{array}$ & & & \\
\hline Stubbs \& Cocklin (2008) & & $\begin{array}{l}\text { Geissdoerfer, V. et al. } \\
\text { (2018) }\end{array}$ & & & \\
\hline Stubbs (2017) & & Hannon et al. (2015) & & & \\
\hline Svensson \& Wagner (2015) & & Morioka et al. (2017) & & & \\
\hline Torielli et al. (2011) & & Scheepens et al. (2016) & & & \\
\hline Tseng et al. (2013) & & Stal \& Corvellec (2018) & & & \\
\hline Witjes \& Lozano (2016) & & $\begin{array}{l}\text { Yang et al. (2017) } \\
\text { Yip \& Bocken (2018) }\end{array}$ & & & \\
\hline
\end{tabular}




\section{SBM's Prevailing Theoretical Approaches}

\subsection{SBM's implementation (Cluster $1, \mathrm{~N}=24$ )}

For Senge \& Carstedt (2001), the development of economically viable and sustainable businesses requires an understanding of rationalism, naturalism, and humanism, and each must be investigated accordingly. Naturalism implies the understanding of how living systems work without creating waste. Following natural principles, industrial systems are advised to employ specific waste reduction strategies such as clean products and remanufacturing. For the authors, organisational learning also helps companies to achieve sustainable development.

Stubbs \& Cocklin (2008) argue that sustainable entrepreneurship contributes to social and environmental problems through successful for-profit businesses. With their research, the authors understand how sustainable entrepreneurship is implemented by exploring a new emerging form of ' $\mathrm{B}$ Corps' business. This model employs market tactics to address social and environmental issues.

Birkin, Cashman et al. (2009) explored the need to establish new sustainable business models using sustainable development, environmental awareness and performance, community responsibility, performance barriers, and sustainability drivers. The authors found a growing concern on the part of companies about the need to use renewable energy, alternative sources of sustainable materials, and close the supply chain cycle by improving the quality of products produced instead of reducing costs, exporting to Europe, and treating employees as assets. A lack of skills, finance, and knowledge prevents the effective incorporation of sustainable development into business modeling and causes underperformance.

Birkin, Polesie et al. (2009) argued that the business model in use by many large companies has changed significantly over a decade and came to incorporate environmental and social performance aspects. However, despite these achievements, are there inevitable inhibitions in the contemporary business model, which means that even exemplary corporations cannot become sustainable? Another fundamental question is about consumption without limits, and can companies take action to address it? The UK Government's Commission on Sustainable Development identifies this as a specific problem. The socio-cultural context might be a key determinant. For example, the authors found that while new tools and management 
approaches specific to Nordic organisations help with sustainable development, and it is the social context in which these organisations operate that is a critical factor.

For Torielli et al. (2011), the lean industry is often seen as a set of tools that reduce the total provoduction cost of manufactured products and improve their quality. The lean toolkit can optimise a firm's efficiency, resembling a process and mindset that needs to be integrated into a firm's systems to achieve sustainability. The authors verified that the lean industry is a model for economic sustainability and environmental management.

Barber et al. (2012) showed how adopting an environmentally sustainable agenda impacts an organisation's supply chain management. The authors argue that today's fragmented/functional approach to sustainability and the conceptualisation of the supply chain as a limited one-way value stream does not provide the holistic approach needed to meet the sustainability needs of tomorrow's businesses. Tseng et al. (2013) identified key factors such as advanced green technology, green consumerism, green innovations, appropriate sustainable business models, green supply chain management, and lean as key concerns and ingredients in promoting large-scale sustainable consumption and production.

Boons et al. (2013) sought to advance sustainable innovation research by adopting a business model perspective. The authors found that research on sustainable innovation tends to neglect the way companies need to combine value propositions, upstream and downstream value chain organisations, and a resolute financial model to bring sustainable innovations to market. Similarly, Boons \& Luedeke-Freund (2013) argued that sustainable development requires radical and systemic innovations. These innovations can be created and studied more effectively when built on the concept of business models. This concept provides companies with a holistic framework for visualising and implementing sustainable innovations. For researchers, the concept offers an analytical tool that allows them to assess the interaction between companies', different aspects to create ecological, economic, and social value. The business model concept also provides a link between the individual company and the larger production and consumption system in which it operates.

Matos \& Silvestre (2013) sought to address the lack of empirical analysis of stakeholder interests in sustainable business models. Although, in theory, the importance of sustainable business models has become widely accepted in the literature, little is known about how managers deal with practical issues, such as 
differences in stakeholder interests. The authors propose a combination of approaches that promote a diverse number of local stakeholders, encourage learning and capacity building, and shift stakeholder values from single to multiple objectives are essential to overcome the challenges of conflicting stakeholder interests.

Hogevold et al. (2014) described the corporate rationale and organisational challenges of sustainable business models and the evolution of economic effects, social limits and environmental actions in sustainable business practices. The authors found that there are evolutionary changes as companies move from a continuum of superficial sustainable business models to incorporated sustainable business models and the application of sustainable business practices. The planning, implementation and evaluation of sustainable business models evolve in companies and their supply chains and bleed through to the market and society.

Schneider (2015) argues that to attend corporate sustainability issues successfully, corporate stakeholders need to participate in sustainability accounting and management. In practice, however, participatory sustainability accounting and management are often not feasible. The result is the risk of unbalancing unique aspects of sustainability. Svensson \& Wagner (2015) sought to examine and report how companies implement and manage their SBM and apply sustainable business practices concerning society and markets. They identified a set of corporate sustainability constituents within the triple bottom line's economic, social and environmental categories.

Witjes \& Lozano (2016) argue that the circular economy is but one of the latest concepts to address environmental and socio-economic issues. As Murray et al. (2017) argue, the circular economy represents the most recent attempt to conceptualise economic activity and environmental welfare sustainably. A circular economy aims to turn waste into resources and bridge production and consumption activities. However, there is still little research explaining these aspects. The Witjes \& Lozano article addresses the link between procurement and supply practices to this end. It proposes to move from a traditional public procurement process based on product sales business models to a more service-oriented system. Concurrently, Lewandowski (2016) argues that a comprehensive knowledge of circular business model design is needed to stimulate and promote the circular economy's implementation. Existing business models for the circular economy have limited 
transferability, and there is no comprehensive structure to support all types of companies in designing a circular business model.

Stubbs (2017) argued that organisations will only be sustainable if their dominant neoclassical model is transformed rather than merely complemented by social and environmental priorities. The author developed a "sustainability business model" (SBM) - a model where sustainability concepts shape the firm's strategy and decision-making. The author found that organisations adopting an SBM must develop internal structural and cultural capacities to achieve sustainability at the company level and collaborate with key stakeholders to achieve sustainability in the organisation's system.

For Caldera et al. (2017), the shift towards sustainable processes and products has influenced companies to improve their environmental performance and efficiency. 'Lean thinking' has evolved into 'lean and green thinking' as an intervention directed at organisations implementing sustainable business models that reduce waste, improve material efficiency and subsequently minimise costs. However, the concept of lean and green thinking is still relatively new, and it is not yet clear to many how exactly lean thinking can genuinely contribute to their transformation and sustainability. This research aimed to conduct a systematic review of the literature on implementing lean and green initiatives to lead to sustainable business practices.

Although sustainable innovation is related to sustainable business and the circular economy, its concept was developed by Franceschelli et al. (2018) in the food industry's business models. They concluded that innovative sustainable business models are essential in the food industry, especially for start-ups because the industry itself is closely tied to nature and human respect.

For Brehmer et al. (2018), sustainable innovation requires collaboration across organisational boundaries. The authors focused on how value is created and captured across organisational boundaries by investigating value transfers between the focal organisation and the external network of business model actors. They then concluded that social sustainability in profit and non-profit organisations is usually achieved through an imbalance in value exchanges offset elsewhere in the business model. In terms of business model structure, the authors find that sustainable organisations use the same underlying business model structures that can be found in traditional companies. 
Fonseca et al. (2018) have shown that the evolution towards a new economic model of a circular economy has been advocated and supported; however, research on this topic is limited. The authors have shown that the circular economy is considered a strategic issue and relevant for profitability and value creation. Moreover, the perception is growing that this requires adopting new business models beyond the classic "reduce, reuse and recycle" approach. However, circular economy activities are still relatively modest (fiscal, legal, organisational, etc.), and greater support from supply chain agents and consumers is needed. To this end, the service sector, especially information and communication technology, can play a key role in shifting to the circular economy due to its strategic position between manufacturers and final consumers (Heyes et al., 2018).

Lahti et al. (2018) argue that understanding the circular economy and the ways companies can compete in the circular economy based on these theories is important to establish important new research directions for sustainable business scholars and circular business models. In this sense, and for Leipold \& Petit-Boix (2018), the European Union has recently introduced the circular economy as a high-level strategy to take our societies beyond the limits of growth. These authors show that currently, business stakeholders relate the circular economy predominantly to established practices and technological business models. This leaves considerable scope for innovation in areas such as social or organisational business models.

\subsection{SBM's Challenges (Cluster 2, $\mathrm{N}=14$ )}

Companies are increasingly applying sustainability practices to improve environmental and social responsibility to increase their performance (Upward \& Jones, 2016; Dentchev et al., 2016; Luedeke-Freund \& Dembek, 2017; LuedekeFreund \& Dembek, 2018; Dentchev et al., 2018; Nosratabadi et al., 2019). For Franca et al. (2017), successful businesses increasingly involve understanding the challenges and opportunities associated with society's transition to sustainability and, for example, being able to innovate, design, and build business models that are functional in this context. However, innovation and the design of today's business models often fail to embrace the sustainability dimension sufficiently. The authors concluded that the framework combination of sustainable strategic development and the Business Model Canvas could support innovation and business model design for sustainable 
strategic development and strengthen each additional tool, method, and concept used as part of sustainable business modeling.

Following this approach, Kurucz et al. (2017) explored the role of leadership in enabling and accelerating the impact of strategic sustainability initiatives. The authors created a conceptual model of relational leadership for strategic sustainability, based on practice, which describes specific practices and capabilities to support sustainable strategic development.

For Strandhagen et al. (2017), the trend towards Logistics 4.0 as an element of Industry 4.0 offers possibilities for new business models. Instant exchange of information, automated solutions, and big real-time data analysis are among the features of Logistics 4.0, paving the way for new business models. Thus, the search for business sustainability creates new requirements for manufacturing and logistics operations.

Weissbrod \& Bocken (2017) show how a company seeks innovative activities to create economic, social, and environmental value. Bidmon \& Knab (2018) linked sustainable business models and transition research. They systematically integrated existing knowledge about business models into the well-established multi-level perspective on socio-technical transitions and identified three roles of business models and their respective impacts on transition dynamics: i) business models hinder transitions by reinforcing the stability of the current system (as part of the sociotechnical regime); ii) business models drive transitions by facilitating the process of stabilising technological innovation and its passage from niche to regime level (as intermediaries between the technological niche and the socio-technical regime); and, iii) new business models drive transitions by building a substantial part of a new regime without relying on technological innovation (as non-technological niche innovation).

Biloslavo et al. (2018) believe that business models seem to have stagnated in the technological age and do not fully fit into the era of sustainability. The authors concluded that the structures of existing business models exclude the organizational environment's natural and social aspects. Existing business models also tend to neglect the interrelationships between economic and non-economic actors and the intertemporal trade-offs that exist therein. Thus, these authors propose a new sustainable business model structure called the "value triangle", which explicitly includes society as a core element that incorporates the natural environment, future 
generations, and three co-created and co-delivered values: public, partner, and client. Neumeyer \& Santos (2018) argues that the successful adaptation and creation of sustainable businesses significantly influences the ability to create more environmentally and socially integrated economic systems. SBM are a critical component of this goal. However, the development of sustainable business models is a complex process that requires a supportive entrepreneurial ecosystem. The authors concluded that sustainable entrepreneurs are under-represented compared to conventional entrepreneurs, but their networks are more densely connected.

Finally, Piscicelli et al. (2018) argue that sustainable business models aim to create economic value while benefiting the environment and society. Their wider adoption and diffusion are necessary to address urgent social problems. However, how these models are implemented and what determines their success (or lack thereof) in the marketplace is not yet well understood and deserves further examination.

\subsection{Institutional SBM (Cluster 3, N = 11)}

Atkins et al. (2015) argue that instead of expecting a climate disaster to lead to a paradigm shift in corporate practice, 'monetising' the costs of climate change is a way of encouraging integrated thinking and sustainable business models. Such consideration builds on existing financial and accounting discourse to create a new environmental visibility field that generates environmental awareness among companies and policymakers worldwide.

Hannon et al. (2015) advocate a perspective based on product-service systems. According to the authors, these constitute a family of service-based business models designed to meet our social needs economically, environmentally, and sustainably. In this sense, they put forward five policy recommendations to support the activity of these systems: i) balance between economic incentives and regulatory disincentives; ii) promote indirect policy support; iii) redesign existing market structures; iv) promote locally led PSS activity; and v) create stable policy structures.

Scheepens et al. (2016) call for metrics to analyse complex business models in the circular economy. For example, life cycle assessment is currently the best-defined system for analysing environmental aspects and can analyse circular systems, product-service systems, and recycling systems. Since new sustainable business models are part of the transition to a circular economy, there is a need for combined 
value and ecological load analyses. The authors applied the eco-costs-to-value ratio model based on life cycle assessment to analyse potential adverse environmental effects. The authors concluded that the eco-efficient value creation approach avoids many pitfalls in circular business model design. For example, having a positive result at the product level but having a negative effect at the social level; having a positive effect on the environment but having low perceived customer value to overcome fierce market competition.

For Geissdoerfer et al. (2016), sustainable business model innovation is an emerging topic, but only a few tools are currently available to help companies model sustainable business. The authors argue that through "design thinking" and "sustainable business model innovation", one can refine the creative process of developing sustainable value propositions and improve the overall process of sustainable business modelling. Thus, Morioka et al. (2017) argue that recent trends have led organisations to rethink their role in society and make the organisation reflect that profit may not be the only and most important business performance criterion. The authors concluded that SBMs are not an attempt to deny the businessas-usual perspective but seek to complement that vision by adding a more axiological and systemic approach. In particular, three convergent points were identified in the case studies as relevant efforts to support the integration of sustainability into the SBM value creation and delivery system: i) the connection between the purpose of the business and the values and beliefs of employees; ii) the proactive and clear commitment to solving sustainability problems; and iii) the need for changes at the system level to enable SBMs successfully.

For Yang et al. (2017), sustainability has become one of the key factors for long-term business success. Recent research and practice show that business model innovation is a promising approach to improving manufacturing sustainability. For the authors, a broader understanding of value is needed to promote sustainability. They propose uncaptured value as a new perspective for SBM innovation and develop four forms of uncaptured value: excess value, no value, lost value, and destroyed value. This proposed structure can help companies identify value opportunities that trigger SBM innovation.

Evans et al. (2017) argue that business model innovation has had a recent increase in academic research and business practice. Thus, the circular economy is increasingly seen as a possible solution to address sustainable development 
(Geissdoerfer et al., 2018a, b). An economic system that minimizes resource input and waste (in emissions and energy terms) from the system is expected to mitigate negative impacts without harming growth and prosperity. Geissdoerfer et al. (2018a) discuss the sustainability performance of circular business models and the circular supply chains needed to implement the concept at an organisational level. The authors argue that circular business and circular supply chain help achieve sustainability ambitions. Stal \& Corvellec (2018), based on the concept of decoupling institutional theory from organisational studies, explain how organisations mitigate the challenges of circularity. The authors show how outsourcing and internal separation allow these companies to protect their business model and central way of creating value from emerging challenges. They also show how companies act proactively to influence the institutional demands of circularity, making those demands compatible with corporate interests. In this sense, Yip \& Bocken (2018) argue that innovation in the sustainable business model is increasingly seen as a lever for systems change favouring sustainability.

\subsection{Circular SBM (Cluster 4, $\mathrm{N}=7$ )}

Bocken et al. (2014) argue that eco-innovations, eco-efficiency and corporate social responsibility practices define much of the current industrial sustainability agenda. While they are important, they are insufficient to provide the holistic changes needed to achieve long-term social and environmental sustainability.

Short et al. (2014) thus propose an understanding of the relationship between industrial ecology and business model innovation for sustainability to create new value and competitive advantage, expanding the understanding of industrial symbiosis and internal symbiosis. Concurrently, Bocken et al. (2015) found that pressures on businesses to operate sustainably are increasing. This requires firms to adopt a systemic approach that seeks to integrate consideration of the three dimensions of sustainability—social, environmental and economic — in a way that generates shared value creation for multiple stakeholders, including the environment and society.

This is how sustainable business thinking emerges. This thinking is fundamental to meeting global sustainability challenges (Bocken, 2015). Bocken (2015) argues that significant investments in sustainable business are needed. Venture capital investment has a key role to play in developing sustainable start-ups. The author found that, in addition to financial support, venture capital investors provide 
sustainable business advice. Key success factors include business model innovation and collaborations, while failure factors include a lack of suitable investors, a strong, established industry, and a short-term investor mentality. Sustainable start-ups should focus on triple bottom line business model innovation, finding opportunities in new technologies and financing platforms, and developing various businesses to create success beyond the "green customer base. Sustainable venture capitalists can help prove the success of sustainable business formats, mitigate financial risk through coinvestment, and exercise patience in balancing financial returns with social and environmental returns.

Baldassarre et al. (2017) argue that with a growing population, a growing middle class, and the increasing use of resources, our current ways of living and doing business are unsustainable. With innovative technology implementation and sustainable development based on innovative business models, a better understanding of customer needs and behaviour change is crucial. The authors combined sustainable business model innovation and user-oriented innovation to develop more successful, radical, and user-centred sustainable value propositions.

Baldassarre et al. (2019) suggest a new approach: industrial symbiosis. Industrial symbiosis is a collective approach to gain a competitive advantage in which separate sectors create a cooperative network to exchange materials, energy, water or by-products (e.g., the market for carbon credits). By addressing resource depletion, waste management and pollution, they argue that industrial symbiosis plays an important role in the transition to sustainable development.

Ritala et al. (2018) studied the diversity of sustainable business models adopted by major global corporations, listed in the S\&P 500 index, 2005-2014. They then noted the growing prominence of different types of sustainable business models over time. In particular, the results show that large capitalisation companies have adopted mainly environmentally oriented and, to a much lesser extent, social and organisational archetypes.

\subsection{Emerging SBM (Cluster 5, $\mathrm{N}=4$ )}

Junnila (2008) tested the appropriateness of an input-output life cycle assessment approach in assessing the life cycle impacts of energy-using products on businesses. This study verified the life cycle impacts of three products and assessed the 
approach's appropriateness in the company environment. It then concluded that operational energy use was environmentally important in all energy products.

Joyce \& Paquin (2016) argue that the triple-layered business model canvas is a tool for exploring innovation in the sustainability-oriented business model. The authors believe that two layers should be added to the original business model: an environmental layer based on the life cycle perspective and a social layer based on the stakeholder perspective. When taken together, the three tiers of the business model make more explicit how an organisation generates various types of economic, environmental, and social value. This screening tool forms a visual representation of a business model to assist in developing and communicating a more holistic and integrated vision of a future business model. Therefore, it holds potential forfurther supporting creative innovation towards more sustainable business models. The authors argue that this new tool contributes to SBM research by providing a design tool that structures sustainability issues in business model innovation.

Todeschini et al. (2017) advocate that both new and existing companies seek ways to prosper in a competitive environment with innovative business models, respecting society, and avoiding actions that harm the planet. Trends such as the circular economy, fair trade, and the sharing economy are some of the many emerging entrepreneurial approaches that address this problem. However, the authors also highlight a gap between what extant theory argues and the perceived levels of environmental and social sustainability when the theory is put into practice.

Pal \& Gander (2018) showed that firms' business models in the global fashion industry produce highly negative environmental results. High water usage, pollution from chemical treatments used in dyeing, and preparation of large quantities of unsold stock through incineration or landfill combine to make garments one of the most impacting industries on the planet. The authors used the sustainable logic of narrowing, slowing, and closing the resource cycle used during the production, design, manufacture, and distribution of fashion apparel to evaluate emerging business models that might reduce the environmental impact of fashion supply chains and value chains. Based on the idea of a business model as a system designed to create value for the customer and capture value for the company, these authors added an environmental value consideration. They derived propositions that test the possibility of emerging SBM in fashion by replacing unsustainable dominant models. The authors concluded that lack of scalability, incompatibility with customer value 
propositions in this industry, and obstacles to supply chain change mitigate against the prospect of currently designed sustainable business models. However, the fashion industry is especially complex because many fashion firms run concurrent product lines that rotate seasonally while also maintaining a second line of stable fashion staples (Tran, Zahra \& Hughes, 2019). Their business models are multipart, and so a single approach to sustainability is unlikely to work without specific adaptation to the features of specific short-to-medium-to-long product lines.

\section{Theoretical and Managerial Implications}

This study has direct implications for the literature on sustainable business models (SBM), primarily by identifying the clusters of issues investigated to date, their main results, and their contributions. Thus, it provides the literature a map that allows the scientific community to visualise and understand the landscape of main topics discussed, findings, uncertainties, and future agenda.

Table 5 presents the main managerial implications for each of the prevailing theoretical approaches of SBM (clusters). 
Table 5 - Managerial implication of Prevailing Theoretical Approaches

\begin{tabular}{|c|c|}
\hline $\begin{array}{l}\text { Prevailing } \\
\text { Theoretical } \\
\text { Approaches }\end{array}$ & Managerial implications \\
\hline 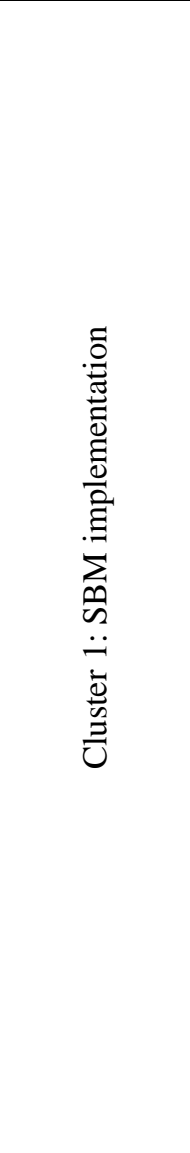 & $\begin{array}{l}\text { - Industrial systems are advised to employ specific waste reduction strategies such as } \\
\text { clean products and renewal. } \\
\text { - Organisational learning helps companies to achieve sustainable development. } \\
\text { - The 'B Corps' model which employs market tactics to address social and } \\
\text { environmental issues. } \\
\text { - Growing concern on the part of business about the need to use renewable energy, } \\
\text { alternative sustainable material sources, and closing the supply chain cycle. } \\
\text { - Lean tools can optimise business efficiency. } \\
\text { - The lean industry is a model of economic sustainability and environmental } \\
\text { management. } \\
\text { - Advanced green technology, green consumerism, green innovations, appropriate } \\
\text { SBM, green supply chain management, and lean are key ingredients in promoting } \\
\text { large-scale consumption and sustainable production. } \\
\text { - Sustainable development requires radical and systemic innovations that translate } \\
\text { into greater effectiveness when built on the concept of business models. } \\
\text { - Circular economy turns waste into resources and bridges production and } \\
\text { consumption activities. } \\
\text { - Organisations will only be sustainable if social and environmental priorities } \\
\text { transform the dominant neoclassical business model. } \\
\text { - Organisations that adopt an SBM must develop internal structural and cultural } \\
\text { capacities to achieve sustainability at the company level and collaborate with } \\
\text { stakeholders to achieve system sustainability. } \\
\text { - Sustainable organisations use the same underlying business model structures that } \\
\text { can be found in traditional companies. } \\
\text { The circular economy is a high-level strategy to take our societies beyond the limits } \\
\text { of growth. } \\
\text { technological business models. }\end{array}$ \\
\hline 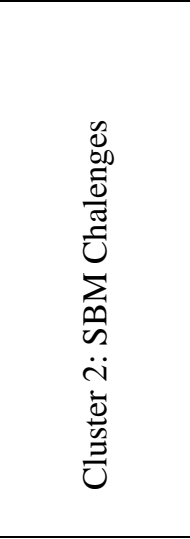 & $\begin{array}{l}\text { - Sustainability practices have improved environmental and social responsibility and } \\
\text { increased performance. } \\
\text { - Successful business involves understanding the challenges and opportunities } \\
\text { associated with society's transition to sustainability. } \\
\text { - The combination structure for sustainable strategic development - business model } \\
\text { canvas can support innovation and business model design for sustainable strategic } \\
\text { development. } \\
\text { - Logistics } 4.0 \text { as an element of Industry } 4.0 \text { offers possibilities for new business } \\
\text { models. } \\
\text { - A new sustainable business model structure explicitly includes society's core } \\
\text { elements that incorporate the natural environment and future generations into three } \\
\text { types of co-created and co-delivered value: public, partner, and customer. } \\
\text { - SBMs aim to create economic value while benefiting the environment and society. }\end{array}$ \\
\hline
\end{tabular}




\begin{tabular}{|l|l|l|}
\hline & $\begin{array}{l}\text { The 'monetisation' of climate change costs is a way of encouraging integrated } \\
\text { thinking and SBM. }\end{array}$ \\
- Product service systems constitute a family of service-based business models \\
designed to meet our social needs economically and environmentally sustainable.
\end{tabular}

\section{Conclusions and Future research agenda}

This study has direct implications for the SBM literature by identifying the themes that have been investigated, their contributions, and main conclusions and trends. It thus provides the literature mapping that allows the scientific community to know the main issues discussed, the findings, the uncertainties, and the future agenda.

Despite the contributions identified, the study has some limitations, notably that only a database was used to collect the articles that were part of the study. Although the WoS database presents itself as an international reference database and 
has been elected for the most part by many studies of this nature, the collection of articles from other databases and sources could provide further insights into SBM analysis.

Hence, and following the structure of the review above studies, our proposed future research agenda derives from the TCCM framework, proposed several authors (Paul \& Rosado-Serrano, 2019; Ferreira et al., 2020), and made up of the following four components: i) Theory (T); ii) Context (C); iii) Characteristics (C); and iv) Methodology (M). Table 6 systematically sets out the TCCM framework components applied in our SBM study.

Table 6 - Contextual, methodological, and future research directions for SBM

\begin{tabular}{|c|c|}
\hline Theory & $\begin{array}{l}\text { What are the most relevant theories in the study of SBM? } \\
\text { - Should new theories be developed? } \\
\text { - Besides those related to business sciences, which disciplines should also be } \\
\text { important in studying SBM (psychology, behavioural sciences, sociology, } \\
\text { technology, engineering sciences)? } \\
\text { - How can existing theory be developed and improved to help explain the } \\
\text { practices and implementation of SBM? } \\
\text { - What approach to SBM has the potential to contribute conceptually to the } \\
\text { development of a broader literature? }\end{array}$ \\
\hline Context & $\begin{array}{l}\text { What are the similarities and differences in the various approaches of SBM? } \\
\text { - What are the similarities and differences between SBMs according to their } \\
\text { strategy and the companies they work? } \\
\text { - What factors explain these differences? } \\
\text { - How important are the different levels (micro, meso, and macro) in the } \\
\text { success or failure of SBM? } \\
\text { - What are the institutional pressures at play? }\end{array}$ \\
\hline Content & $\begin{array}{l}\text { What role do resources and capabilities play in SBM performance? } \\
\text { - What are the factors that measure the SBM-performance ratio of companies? } \\
\text { - How do contextual logics relate to SBM? } \\
\text { - What is the role of researchers' perception of SBM in shaping organisational } \\
\text { results? }\end{array}$ \\
\hline Method & $\begin{array}{l}\text { How can we measure SBM? } \\
\text { - How can we measure the impact between a traditional company and a } \\
\text { sustainable one? Are they different or similar metrics? } \\
\text { - Do the different levels of SBM analysis require different methods? } \\
\text { - How can we combine various methods to explore SBM from different levels } \\
\text { of analysis? } \\
\text { - Can we develop large-scale databases to measure SBM performance? } \\
\text { - Can we use existing methods, or do we need innovative methods and look for } \\
\text { other disciplines to effectively explain SBM? }\end{array}$ \\
\hline
\end{tabular}

This study aimed to map scientific publications, intellectual structure, and research trends in sustainable business models (SBM). First, the aim was to identify the fundamental contributions of research in this area of knowledge, and second, a further 
aim was to determine the predominant theoretical research approaches in this area of knowledge.

Given our starting research question, what are the prevailing theoretical approaches in the study of sustainable business models (SBMs)?, it can be noted that SBMs can have different approaches and components depending on the academic and management context. On the one hand, the triple bottom line is essential; but on the other hand, stakeholder requirements are not uniform across stakeholder groups, and stakeholders themselves compete to impose their worldview and preferences. Their knowledge of what consistute the advantages (and costs) of different models of sustainable business modelling is also problematic for the firm. Sustainable business modelling then requires some inherent trade-offs that warrant further attention.

An SBM should link archetypes of sustainable business models with social connections, and individual and organisational level factors presented here incorporate ideas from the sustainability literature, entrepreneurship, and network theory. The integration of different ideas can build a basis for a more subtle understanding of how different SBM types are socially embedded in entrepreneurial ecosystems.

\section{References}

Atkins, J., Atkins, B. C., Thomson, I., \& Maroun, W. (2015). 'Good' news from nowhere: imagining utopian sustainable accounting. Accounting Auditing \& Accountability Journal, 28(5, SI), 651-670. https://doi.org/10.1108/AAAJ-092013-1485.

Baldassarre, B., Calabretta, G., Bocken, N. M. P., \& Jaskiewicz, T. (2017). Bridging sustainable business model innovation and user-driven innovation: A process for sustainable value proposition design. Journal of Cleaner Production, 147, 175186. https://doi.org/10.1016/j.jclepro.2017.01.081.

Baldassarre, B., Schepers, M., Bocken, N., Cuppen, E., Korevaar, G., \& Calabretta, G. (2019). Industrial Symbiosis: towards a design process for eco-industrial clusters by integrating Circular Economy and Industrial Ecology perspectives. Journal of Cleaner Production, 216, 446-460. https://doi.org/10.1016/j.jclepro.2019.01.091.

Barber, K. D., Beach, R., \& Zolkiewski, J. (2012). Environmental sustainability: a value cycle research agenda. Production Planning \& Control, 23(2-3, SI), 105119. https://doi.org/10.1080/09537287.2011.591621.

Bidmon, C. M., \& Knab, S. F. (2018). The three roles of business models in societal transitions: New linkages between business model and transition research. Journal of Cleaner Production, 178, 903-916. https://doi.org/10.1016/j.jclepro.2017.12.198.

Biloslavo, R., Bagnoli, C., \& Edgar, D. (2018). An eco-critical perspective on 
business models: The value triangle as an approach to closing the sustainability gap. Journal of Cleaner Production, 174, 746-762. https://doi.org/10.1016/j.jclepro.2017.10.281.

Birkin, F., Cashman, A., Koh, S. C. L., \& Liu, Z. (2009). New Sustainable Business Models in China. Business Strategy and the Environment, 18(1), 64-77. https://doi.org/10.1002/bse.568.

Birkin, F., Polesie, T., \& Lewis, L. (2009). A New Business Model for Sustainable Development: an Exploratory Study Using the Theory of Constraints in Nordic Organizations. Business Strategy and the Environment, 18(5), 277-290. https://doi.org/10.1002/bse.581.

Bocken, N. M. P. (2015). Sustainable venture capital - catalyst for sustainable start-up success? Journal of Cleaner Production, 108(A), 647-658. https://doi.org/10.1016/j.jclepro.2015.05.079.

Bocken, N. M. P., Rana, P., \& Short, S. W. (2015). Value mapping for sustainable business thinking. Journal of Industrial and Production Engineering, 32(1), 6781. https://doi.org/10.1080/21681015.2014.1000399.

Bocken, N. M. P., Short, S. W., Rana, P., \& Evans, S. (2014). A literature and practice review to develop sustainable business model archetypes. Journal of Cleaner Production, 65, 42-56. https://doi.org/10.1016/j.jclepro.2013.11.039.

Boons, F., \& Luedeke-Freund, F. (2013). Business models for sustainable innovation: state-of-the-art and steps towards a research agenda. Journal of Cleaner Production, 45, 9-19. https://doi.org/10.1016/j.jclepro.2012.07.007.

Boons, F., Montalvo, C., Quist, J., \& Wagner, M. (2013). Sustainable innovation, business models and economic performance: an overview. Journal of Cleaner Production, 45, 1-8. https://doi.org/10.1016/j.jclepro.2012.08.013.

Borgatti, S. P. (2002). NetDraw: Graph visualisation software. Harvard: MA: Analytic Technologies.

Brehmer, M., Podoynitsyna, K., \& Langerak, F. (2018). Sustainable business models as boundary-spanning systems of value transfers. Journal of Cleaner Production, 172, 4514-4531. https://doi.org/10.1016/j.jclepro.2017.11.083.

Caldera, H. T. S., Desha, C., \& Dawes, L. (2017). Exploring the role of lean thinking in sustainable business practice: A systematic literature review. Journal of Cleaner Production, 167, 1546-1565. https://doi.org/10.1016/j.jclepro.2017.05.126.

Dentchev, N., Baumgartner, R., Dieleman, H., Johannsdottir, L., Jonker, J., Nyberg, T., ... van Hoof, B. (2016). Embracing the variety of sustainable business models: social entrepreneurship, corporate intrapreneurship, creativity, innovation, and other approaches to sustainability challenges. Journal of Cleaner Production, 113, 1-4. https://doi.org/10.1016/j.jclepro.2015.10.130.

Dentchev, N., Rauter, R., Johannsdottir, L., Snihur, Y., Rosano, M., Baumgartner, R., ... Jonker, J. (2018). Embracing the variety of sustainable business models: A prolific field of research and a future research agenda. Journal of Cleaner Production, 194, 695-703. https://doi.org/10.1016/j.jclepro.2018.05.156.

Evans, S., Vladimirova, D., Holgado, M., Van Fossen, K., Yang, M., Silva, E. A., \& Barlow, C. Y. (2017). Business Model Innovation for Sustainability: Towards a Unified Perspective for Creation of Sustainable Business Models. Business Strategy and the Environment, 26(5), 597-608. https://doi.org/10.1002/bse.1939.

Ferasso, M., Beliaeva, T., Kraus, S., Clauss, T., \& Ribeiro-Soriano, D. (2020). Circular economy business models: The state of research and avenues ahead. Business Strategy and the Environment, 29(8), 3006-3024. 
Fernandes, C.I., Veiga, P.M., Ferreira, J.J.M., and Hughes, M. (2020), "Green growth versus economic growth: Do sustainable technology transfer and innovations lead to an imperfect choice?", Business Strategy and the Environment, https://doi.org/10.1002/bse.2730.

Ferreira, J. J., Fernandes, C. I., \& Kraus, S. (2019). Entrepreneurship research: mapping intellectual structures and research trends. Review of Managerial Science, 13(1), 181-205.

Ferreira, J., Fernandes, C. \& Ratten, V. (2019). The Effects of Technology Transfers and Institutional Factors on Economic Growth: Evidence from Europe and Oceania. The Journal of Technology Transfer, 44, 1505-1528.

Ferreira, J. J. M., Fernandes, C., \& Veiga, P. (2020). Multilevel approaches to advancing the measurement of intellectual capital research field-What can we learn from the literature? Journal of Intellectual Capital, ahead-of-print(aheadof-print). doi:10.1108/jic-07-2020-0221

Filser, M., Kraus, S., Roig-Tierno, N., Kailer, N., \& Fischer, U. (2019). Entrepreneurship as catalyst for sustainable development: opening the black box. Sustainability, 11(16), 4503.

Fonseca, L. M., Domingues, J. P., Pereira, M. T., Martins, F. F., \& Zimon, D. (2018). Assessment of Circular Economy within Portuguese Organisations. Sustainability, 10(7). https://doi.org/10.3390/su10072521.

Franca, C. L., Broman, G., Robert, K.-H., Basile, G., \& Trygg, L. (2017). An approach to business model innovation and design for strategic sustainable development. Journal of Cleaner Production, 140(1, SI), 155-166. https://doi.org/10.1016/j.jclepro.2016.06.124.

Franceschelli, M. V., Santoro, G., \& Candelo, E. (2018). Business model innovation for sustainability: a food start-up case study. British Food Journal, 120(10), 2483-2494. https://doi.org/10.1108/BFJ-01-2018-0049.

Gali, N.K., Niemand, T., Shaw, E., Hughes, M., Kraus, S., and Brem, A. (2020), "Social entrepreneurship orientation and company success: The mediating role of social performance", Technological Forecasting \& Social Change, 160(November), 120230. DOI: 10.1016/j.techfore.2020.120230

Geissdoerfer, M., Bocken, N. M. P., \& Hultink, E. J. (2016). Design thinking to enhance the sustainable business modelling process - A workshop based on a value mapping process. Journal of Cleaner Production, 135, 1218-1232. https://doi.org/10.1016/j.jclepro.2016.07.020.

Geissdoerfer, M., Morioka, S. N., de Carvalho, M. M., \& Evans, S. (2018a). Business models and supply chains for the circular economy. Journal of Cleaner Production, 190, 712-721. https://doi.org/10.1016/j.jclepro.2018.04.159.

Geissdoerfer, M., Vladimirova, D., \& Evans, S. (2018b). Sustainable business model innovation: A review. Journal of Cleaner Production, 198, 401-416. https://doi.org/10.1016/j.jclepro.2018.06.240.

Goni, F.A., Chofreh, A.G., Mukhtar, M., Sahran, S., Shukor, S.A., Klemes, J.J. (2017). Strategic alignment between sustainability and information systems: a case analysis in Malaysian public Higher Education Institutions. Journal of Cleaner Production, 168, 263-270.

Hannon, M. J., Foxon, T. J., \& Gale, W. F. (2015). 'Demand pull' government policies to support Product-Service System activity: the case of Energy Service Companies (ESCos) in the UK. Journal of Cleaner Production, 108(A), 900915. https://doi.org/10.1016/j.jclepro.2015.05.082.

Heyes, G., Sharmina, M., Mendoza, J. M. F., Gallego-Schmid, A., \& Azapagic, A. 
(2018). Developing and implementing circular economy business models in service-oriented technology companies. Journal of Cleaner Production, 177, 621-632. https://doi.org/10.1016/j.jclepro.2017.12.168.

Hogevold, N. M., Svensson, G., Wagner, B., Petzer, D. J., Klopper, H. B., Varela, J. C. S., ... Ferro, C. (2014). Sustainable business models Corporate reasons, economic effects, social boundaries, environmental actions and organisational challenges in sustainable business practices. Baltic Journal of Management, 9(3), 357-380. https://doi.org/10.1108/BJM-09-2013-0147.

Joyce, A., \& Paquin, R. L. (2016). The triple layered business model canvas: A tool to design more sustainable business models. Journal of Cleaner Production, 135, 1474-1486. https://doi.org/10.1016/j.jclepro.2016.06.067.

Junnila, S. (2008). Life cycle management of energy-consuming products in companies using IO-LCA. International Journal of Life Cycle Assessment, 13(5), 432-439. https://doi.org/10.1007/s11367-008-0015-y.

Kraus, S., Breier, M., \& Dasí-Rodríguez, S. (2020). The art of crafting a systematic literature review in entrepreneurship research. International Entrepreneurship and Management Journal, 16(3), 1023-1042.

Kraus, S., Burtscher, J., Vallaster, C., \& Angerer, M. (2018). Sustainable entrepreneurship orientation: A reflection on status-quo research on factors facilitating responsible managerial practices. Sustainability, 10(2), 444.

Kurucz, E. C., Colbert, B. A., Luedeke-Freund, F., Upward, A., \& Willard, B. (2017). Relational leadership for strategic sustainability: practices and capabilities to advance the design and assessment of sustainable business models. Journal of Cleaner Production, 140(1, SI), 189-204. https://doi.org/10.1016/j.jclepro.2016.03.087.

Lahti, T., Wincent, J., \& Parida, V. (2018). A Definition and Theoretical Review of the Circular Economy, Value Creation, and Sustainable Business Models: Where Are We Now and Where Should Research Move in the Future? Sustainability, 10(8). https://doi.org/10.3390/su10082799.

Leipold, S., \& Petit-Boix, A. (2018). The circular economy and the bio-based sector Perspectives of European and German stakeholders. Journal of Cleaner Production, 201, 1125-1137. https://doi.org/10.1016/j.jclepro.2018.08.019.

Lewandowski, M. (2016). Designing the Business Models for Circular EconomyTowards the Conceptual Framework. Sustainability, 8(1). https://doi.org/10.3390/su8010043.

Lüdeke-Freund, F. (2009). Business Model Concepts in Corporate Sustainability Contexts. From Rhetoric to a Generic Template for 'Business Models for Sustainability", Center for Sustainability Management (CSM), Lüneburg: Leuphana Universität, Lüneburg.

Lüdeke-Freund, F. (2010). Towards a conceptual framework of business models for sustainability, Knowledge Collaboration \& Learning for Sustainable Innovation ERSCP-EMSU conference, Delft, The Netherland, October 25-29, pp.1-28.

Luedeke-Freund, F., Carroux, S., Joyce, A., Massa, L., \& Breuer, H. (2018). The sustainable business model pattern taxonomy-45 patterns to support sustainability-oriented business model innovation. Sustainable Production and Consumption, 15, 145-162. https://doi.org/10.1016/j.spc.2018.06.004.

Luedeke-Freund, F., \& Dembek, K. (2017). Sustainable business model research and practice: Emerging field or passing fancy? Journal of Cleaner Production, 168, 1668-1678. https://doi.org/10.1016/j.jclepro.2017.08.093.

Mas-Tur, A., Kraus, S., Brandtner, M., Ewert, R., \& Kürsten, W. (2020). Advances in 
management research: a bibliometric overview of the Review of Managerial Science. Review of Managerial Science, 14(5), 933-958.

Matos, S., \& Silvestre, B. S. (2013). Managing stakeholder relations when developing sustainable business models: the case of the Brazilian energy sector. Journal of Cleaner Production, 45, 61-73. https://doi.org/10.1016/j.jclepro.2012.04.023.

Morioka, S. N., Bolis, I., Evans, S., \& Carvalho, M. M. (2017). Transforming sustainability challenges into competitive advantage: Multiple case studies kaleidoscope converging into sustainable business models. Journal of Cleaner Production, 167, 723-738. https://doi.org/10.1016/j.jclepro.2017.08.118.

Murray, A., Skene, K., \& Haynes, K. (2017). The Circular Economy: An Interdisciplinary Exploration of the Concept and Application in a Global Context. Journal of Business Ethics, 140(3), 369-380. https://doi.org/10.1007/s10551-015-2693-2.

Neumeyer, X., \& Santos, S. C. (2018). Sustainable business models, venture typologies, and entrepreneurial ecosystems: A social network perspective. Journal of Cleaner Production, 172, 4565-4579. https://doi.org/10.1016/j.jclepro.2017.08.216.

Nosratabadi, S., Mosavi, A., Shamshirband, S., Zavadskas, E. K., Rakotonirainy, A., \& Chau, K. W. (2019). Sustainable Business Models: A Review. Sustainability, 11(6). https://doi.org/10.3390/su11061663.

Pal, R., \& Gander, J. (2018). Modelling environmental value: An examination of sustainable business models within the fashion industry. Journal of Cleaner Production, 184, 251-263. https://doi.org/10.1016/j.jclepro.2018.02.001.

Paul, J. \& Rosado-Serrano, A. (2019). Gradual Internationalization vs BornGlobal/International new venture models: A review and research

Powell, T.H. and Hughes, M. (2016), "Exploring Value as the Foundation of Value Proposition Design", Journal of Business Models, 4(1), 2944.agenda. International Marketing Review, 36(6), 830-858.

Piscicelli, L., Ludden, G. D. S., \& Cooper, T. (2018). What makes a sustainable business model successful? An empirical comparison of two peer-to-peer goodssharing platforms. Journal of Cleaner Production, 172, 4580-4591. https://doi.org/10.1016/j.jclepro.2017.08.170.

Rahman, M., Aziz, S., and Hughes, M. (2020), "The product-market performance benefits of environmental policy: Why customer awareness and firm innovativeness matter", Business Strategy and the Environment, 29(5), 20012018. DOI: $10.1002 / \mathrm{bse} .2484$

Raposo, M. Fernandes, C \& Veiga, P. (2020). National systems of entrepreneurship: goals of sustainability. Journal of Entrepreneurship and Public Policy, 9 (4), 345-364. https://doi.org/10.1108/JEPP-04-2020-0018.

Ritala, P., Huotari, P., Bocken, N., Albareda, L., \& Puurnalainen, K. (2018). Sustainable business model adoption among S\&P 500 firms: A longitudinal content analysis study. Journal of Cleaner Production, 170, 216-226. https://doi.org/10.1016/j.jclepro.2017.09.159.

Rudnicka, A. (2016). Understanding sustainable business models. Journal of Positive Management. 7(4), 52-60.

Scheepens, A. E., Vogtlander, J. G., \& Brezet, J. C. (2016). Two life cycle assessment (LCA) based methods to analyse and design complex (regional) circular economy systems. Case: making water tourism more sustainable. Journal of Cleaner Production, 114, 257-268. https://doi.org/10.1016/j.jclepro.2015.05.075. 
Schneider, A. (2015). Reflexivity in Sustainability Accounting and Management: Transcending the Economic Focus of Corporate Sustainability. Journal of Business Ethics, 127(3), 525-536. https://doi.org/10.1007/s10551-014-2058-2.

Senge, P. M., \& Carstedt, G. (2001). Innovating our way to the next industrial revolution. MIT Sloan Management Review, 42(2), 24+.

Short, S. W., Bocken, N. M. P., Barlow, C. Y., \& Chertow, M. R. (2014). From Refining Sugar to Growing Tomatoes Industrial Ecology and Business Model Evolution. Journal of Industrial Ecology, 18(5), 603-618. https://doi.org/10.1111/jiec.12171.

Stal, H. I., \& Corvellec, H. (2018). A decoupling perspective on circular business model implementation: Illustrations from Swedish apparel. Journal of Cleaner Production, 171, 630-643. https://doi.org/10.1016/j.jclepro.2017.09.249.

Strandhagen, J. O., Vallandingham, L. R., Fragapane, G., Strandhagen, J. W., Stangeland, A. B. H., \& Sharma, N. (2017). Logistics 4.0 and emerging sustainable business models. Advances in Manufacturing, 5(4, SI), 359-369. https://doi.org/10.1007/s40436-017-0198-1.

Stubbs, W. (2017). Sustainable Entrepreneurship and B Corps. Business Strategy and The Environment, 26(3), 331-344. https://doi.org/10.1002/bse.1920.

Stubbs, W., \& Cocklin, C. (2008). Conceptualising a 'sustainability business model'. $\begin{array}{llll}\text { Organization } \& \text { Environment, } & \text { 21(2), }\end{array}$ https://doi.org/10.1177/1086026608318042.

Svensson, G., \& Wagner, B. (2015). Implementing and managing economic, social and environmental efforts of business sustainability Propositions for measurement and structural models. Management of Environmental Quality, 26(2), 195-213. https://doi.org/10.1108/MEQ-09-2013-0099.

Todeschini, B. V., Cortimiglia, M. N., Callegaro-de-Menezes, D., \& Ghezzi, A. (2017). Innovative and sustainable business models in the fashion industry: Entrepreneurial drivers, opportunities, and challenges. Business Horizons, 60(6, SI), 759-770. https://doi.org/10.1016/j.bushor.2017.07.003.

Torielli, R. M., Abrahams, R. A., Smillie, R. W., \& Voigt, R. C. (2011). Using lean methodologies for economically and environmentally sustainable foundries. China Foundry, 8(1), 74-88.

Tran, Y., Zahra, S., and Hughes, M. (2019), “A Process Model of the Maturation of a New Dynamic Capability”, Industrial Marketing Management, 83, 115-127.

Tseng, M.-L., Chiu, (Anthony) Shun Fung, Tan, R. R., \& Siriban-Manalang, A. B. (2013). Sustainable consumption and production for Asia: sustainability through green design and practice. Journal of Cleaner Production, 40, 1-5. https://doi.org/10.1016/j.jclepro.2012.07.015.

Upward, A., \& Jones, P. (2016). An Ontology for Strongly Sustainable Business Models: Defining an Enterprise Framework Compatible With Natural and Social Science. Organization \& Environment, 29(1, SI), 97-123. https://doi.org/10.1177/1086026615592933.

Weissbrod, I., \& Bocken, N. M. P. (2017). Developing sustainable business experimentation capability - A case study. Journal of Cleaner Production, 142(4), 2663-2676. https://doi.org/10.1016/j.jclepro.2016.11.009.

White, H. D., \& McCain, K. W. (1998). Visualising a discipline: An author cocitation analysis of information science, 1972-1995. Journal of the American Society for Information Science, 49(4), 327-355.

Witjes, S., \& Lozano, R. (2016). Towards a more Circular Economy: Proposing a framework linking sustainable public procurement and sustainable business 
models. Resources Conservation and Recycling, 112, 37-44. https://doi.org/10.1016/j.resconrec.2016.04.015.

Yang, M., Evans, S., Vladimirova, D., \& Rana, P. (2017). Value uncaptured perspective for sustainable business model innovation. Journal of Cleaner Production, 140(3), 1794-1804. https://doi.org/10.1016/j.jclepro.2016.07.102.

Yip, A. W. H., \& Bocken, N. M. P. (2018). Sustainable business model archetypes for the banking industry. Journal of Cleaner Production, 174, 150-169. https://doi.org/10.1016/j.jclepro.2017.10.190. 